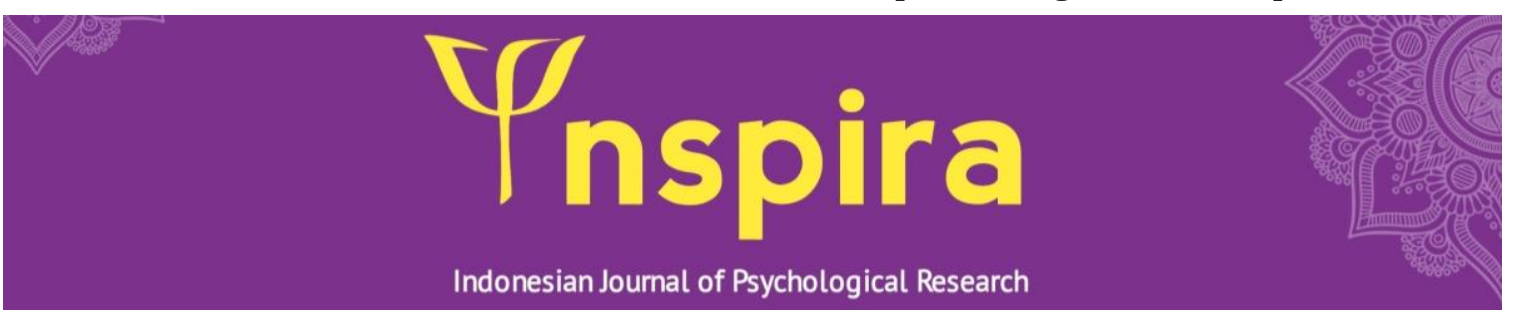

\title{
Coping strategy of a single mother in overcoming child inferiority attitude
}

Novita Sari ${ }^{1}, Z^{2} u l k a r n a i n^{2}$, Marimbun $^{1 凶}$

${ }^{1}$ Department of Islamic Guidance and Counseling, Institut Agama Islam Negeri Langsa, Aceh, Indonesia;

2 Department of Islamic Communication and Broadcasting, Institut Agama Islam Negeri Langsa, Aceh, Indonesia

\section{${ }^{凶}$ Corresponding author:}

Marimbun (email: marimbun.kauman@gmail.com)

\begin{abstract}
Inferiority can arise for children who do not get the father's role, especially when comparing themselves to their friend who still has a father. This study aims to find out the inferiority attitude displayed by children who have a single mother and know the coping strategies of single-parent mothers overcoming the child's inferiority attitude. The study subjects were three singleparent mothers in Gampong Birem Puntong Kota Langsa whose children had inferiority and families with purposive sampling techniques. The research method used is qualitative with a descriptive approach-data collection techniques through observation and interviews. The data analysis was done by data reduction, data presentation, and verification or inference of data. The results showed that the inferiority displayed by children who have a single mother arises due to losing a father figure. Single mother coping strategies overcome the child's inferiority by making a plan that is arranged according to the needs of the child, then carrying it out in accordance with the right time, overcoming obstacles when carrying it out, and having the last step in the form of follow-up to evaluate and supervise every development experienced by the child.
\end{abstract}

How to cite (APA $7^{\text {th }}$ Edition)

Sari, N., Zulkarnain, \& Marimbun. (2021). Coping strategy of a single mother in overcoming child inferiority attitude. INSPIRA: Indonesian Journal of Psychological Research, 2(2), 41-49. https://doi.org/10.32505/inspira.v2i2. 3133

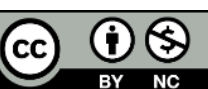

This is an open-access article distributed under the Creative Commons Attribution License, which permits unrestricted use, distribution, and reproduction in any medium provided the original work is properly cited. This is enabled under the terms of attribution and noncommercial usage of the material. (C2021 by Sari, N., Zulkarnain, \& Marimbun. 


\section{INTRODUCTION}

The family becomes a fundamental primary group in a society formed from the father, mother, and child relationship. Family bonding begins with marriage which is an absolute requirement to form a family (Ahmadi, 2007; Andayani, 2016; Kamalin, 2020). The purpose of marriage is to obtain a valid offspring recognized by the community by forming an ideal household known in the term of sakinah, mawaddah wa rahmah family (Akhzani, 2020; Ministry of Religious Affairs, 2009; Gustiawati \& Lestari, 2018; Matul Hikmah, 2020). A whole family has complete members such as a father, mother, and children. Conversely, the absence of the role of one parent due to death or divorce exerts a different influence on the development of the child (Ahmadi, 2007; Hasibuan, 2016; Septianita et al., 2019).

The phenomenon in the field is that many mothers educate their children alone, either because of divorce or death. Mothers take care of their children without a husband figure, often called single mothers (Damayanti \& Dewi, 2017; Novitasari, 2020). Children who do not get attention from their fathers harm the development of children. One of the effects is inferiority (Andriana, 2020). Humans begin to live in small, weak, inferiority (Munawaroh \& Christiana, 2021; Silvyana, 2018). Inferiority includes feelings of worthlessness due to the psychological inability to feel deprived and comparing themselves to children who have a complete family (Muttaqien, 2013; Yulilla, 2017). While the characteristics of people who feel inferiority can be seen from their behavior. The behavior of inferiority among others (1) Always alone and withdraw from the association. People who do not have meaningful abilities do not want to get along and withdraw from the association. (2) Always hesitate in acting. People who feel they do not have a meaningful ability will always hesitate in acting. Such a feeling would be self-defeating. (3) Do not want to compete positively, such as clever competition, fabricating, and bicycle racing (Agustiani, 2019). A person's weakness will result in feeling inferior. Feeling excessive inferiority can affect mental health. Conversely, a person's ability to overcome feelings of inferiority will make the soul healthy and strive towards perfection and happiness (Alwisol, 2009).

Based on the facts in the field, single mothers in Gampong Birem Puntong related to a series of particular problems in raising their children. Single mothers are concerned, especially about family costs, so they have to work alone while providing education and raising their children. While the child of a single mother is often moody when they see their friends have a whole family that she considers luckier so that the child likes to stay at home. In addition, the child feels inferior when the friends tell him about family intact. Of course, this condition presents a problem of single mothers overcoming the inferiority of their children. A single parent is not an option, but the status is forced to be carried because of divorce or the husband's death. Therefore, it takes tremendous energy to carry out the task of bearing the burden of education and the needs of children. They must be physically strong because they must make a living for their children (Linuwih, 2020).

Some of the results of previous research related to the struggle of life as a single parent that single parents must open a business (work), educate and raise children (Layliyah, 2013). The results of Julia et al. (2019), the application of parenting in the context of emotional maturity of single mothers leads to permissive parenting. A busy single mother in carrying out two roles so that the time to accompany and pay attention to children's activities is not maximal. At the same time, some single parents apply democratic parenting, such as being open, caring, prioritizing 
compassion and responsibility. Isma's research (2016) explained that single parents must perform a dual role. Act as a father as well as a mother. Giving a dual role is not an easy thing primarily related to education. The condition's demands will be a burden that can cause stress, and if left, it will affect mental health (Fitria et al., 2021). Therefore. There needs to be a coping strategy that single parents must do in caring for their children.

Some of the results of previous research related to coping strategies include Coping strategies conducted by Ahsyari (2014), that single parents do problem-focused coping such as reducing the intensity of work, positive activities, and hard work. While emotional-focused coping, single parents are looking for various kinds of busyness, expanding association, closing themselves about divorce, being patient, sincere, taking wisdom every problem, and getting closer to God. Furthermore, Nabit et al. (2019) found that the coping strategy used is emotionalfocused coping and problem-focused coping. This study explores coping strategies carried out by single mothers to overcome the inferiority attitude that arises in children.

\section{RESEARCH METHOD}

This study uses qualitative with a descriptive approach (Arikunto, 2014). Participants in the study were three single mothers and their children aged 9-12 years. To add information, researchers also engaged other family members. This research was conducted in Gampong Birem Puntong, Kota Langsa Aceh, Indonesia. Data is collected through an in-depth interview process as well as participatory observations. Then, the data obtained is analyzed continuously until it gets patterns that form conclusions (Sugiyono, 2017). Data analysis adopts techniques proposed by Miles and Huberman through data reduction, data presentation, verification, or data inference.

\section{RESULT}

Inferiority is an attitude of feeling when feeling imperfect, incomplete, and having flaws. The nature of inferiority leads to the problem of low self-concept, as happens to children who lose a father figure either because they die or the father has divorced the mother. Based on the interviews with three families of single mothers obtained an explanation about the inferiority displayed by children who have single mothers in Gampong Birem Puntong Kota Langsa. One of the families who became informants was Siti (pseudonym), a single mother due to divorce from her husband. Siti works as a domestic assistant in one of the housing estates around Birem Puntong. From the results of the interview with Siti, researchers get information about the inferiority displayed by her son, as follows: "Since separating or divorcing my husband, my son's attitude changed, he was more silent and liked to be in the house alone, although the association with friends was fine, he preferred not to leave the house. Similarly, Iyus (pseudonym), a single mother (her husband died), worked as a small trader in the market.

The inferiority attitude displayed by the son based on the results of the interview is as follows: "He prefers to stay at home rather than play with peers who are in the neighborhood around the house, thus causing the association with friends less good." Furthermore, Suti (pseudonym), a single mother who works as a trader in Hutan Kota Langsa. Previously Suti only worked as a housewife, but since her husband died, she took the initiative to trade/sell food around the protected forest park. Based on the results of the interview regarding the inferiority 
displayed by her son, he gave the following statement: "If there are friends to enter the race, both at school and at home, then he will reject it. Despite never playing with friends, my son's attitude towards his friends is fine."

From the interview results that researchers get from the three mothers above, it can be concluded that the inferiority displayed by children is caused by the loss of an important figure in life, namely a father who has been beside him. The study results did not see the difference in the inferiority attitude of children who lost a father due to divorce and the father's loss caused by death. Children who do not get the role of father can result in inferiority towards the child. Since the loss of the father's role can change the attitude of these children, children prefer to be alone at home rather than playing with their peers around the home environment.

Children who do not get the role of father can give birth to an attitude of inferiority. However, not all children who do not get the role of father will experience this lousy attitudehowever, the inferior attitude experienced by children who become informants of researchers. One of the informants interviewed was Sandi (pseudonym), of class VI student, following the caption: "When my father died, I was hospitalized because I was too sad. After the incident, I withdrew from the association with friends and preferred to be alone at home. The same thing was felt by Darul (pseudonym), a class VI student. Darul's description of the low self-esteem that appears can be explained below: "I like to be alone and prefer to follow my mother to sell than play with friends since you have died" Inferior attitude is born from feeling less than others, especially when comparing myself to friends who still have fathers. Based on the results of interviews with children who experience inferiority due to the absence of a father. Since being left by the father, the children's attitude changed. The child prefers to spend time at home rather than play with friends.

The inferior attitude experienced by children in Gampong Birem Puntong Kota Langsa needs to be overcome so that the inferior attitude does not continue until adulthood, hindering social relations in society. Therefore. There needs to be a coping strategy that the mother must do. As a single parent, her mother must have a dual role for her family. The dual role includes meeting children's psychological needs, such as providing a sense of security, affection, and attention. In addition, single parents must meet children's physical needs, including food needs, education, health, and other needs. This means that single mothers must be able to divide their time between homework and work outside the home so that children can feel the affection of their parents and fulfill them. Likewise, with the life of single mothers in Gampong Birem Puntong Kota Langsa where single mothers have to work to meet their living needs such as being domestic assistants (maids), traders in the market, and traders/selling in tourist attractions, so that the form of attention and affection is reduced. In order for the mother to carry out her duties as a single parent, as a single mother, she needs to make an action or effort to face the problems she faces. The effort in question is commonly called coping. Single mothers carried out the coping strategy in Gampong Birem Puntong Kota Langsa by making several plans prepared based on their initiative. The child also knows that the planning that has been made by the mother, following the results of interviews with three families of single mothers, obtained explanations or information about the coping strategy of single mothers overcoming the inferiority of children in Gampong Birem Puntong Kota Langsa. 
First, the researcher got information from Siti about the coping strategies she did in overcoming the son's inferiority was as follows: "The planning I made there are many such as providing support, direction, attention, supervising the learning and most importantly is to bring the child closer to the uncle so that the figure of a father who has been irreplaceable by the presence of an uncle. The implementation stage is done gradually in accordance with the needs of the child. Nevertheless, not everything can be done simultaneously and smoothly. There must be obstacles that inhibit, while the perceived obstacle is time because my busy work must hinder my planning time. Therefore, to overcome these obstacles, if the time off has arrived, then I invite children to go on vacation/sightseeing to tourist attractions." Second, the researchers got information from Iyus about the coping strategies she did in overcoming the child's inferiority attitude is as follows: "My planning in overcoming inferiority is to provide motivation, support, positive outlook, build confidence, tell children to play outside the home and provide things that make him happy. For the implementation stage, I do it gradually and prioritize planning in accordance with the condition of the child. However, in every plan that has been made, the problem of time is the current obstacle. Thus, to carry out the planning must have free time such as going to tourist attractions while buying things that my child likes." Third, the researcher got information from Suti about the coping strategies she did in overcoming the son's inferiority was as follows: "For the planning I made was to provide support, compassion, advice, motivation and encourage to be able to play outside with friends. While in its implementation is still constrained by time, but to outsmart it in every good time, then I will carry out the plan and prioritize what is needed by my son."

The results of the interview that researchers get from the three mothers, it can be concluded that the coping strategy of single mothers problem-focused coping in overcoming the inferiority of children is to do the planning, carry out planning, overcome the obstacles that are time such as by taking a vacation or finding the best time to carry out the planning. Meanwhile, after the planning and implementation stage is carried out, the children can feel the results, such as one of the children named Rani (pseudonym), said: "I know the mother is making plans to change my attitude. I often give them advice and motivation that you give me, so now I am more eager to learn seriously in order to make my mother happy in the future." From the interview results that the researchers above, it can be concluded that planning and stages of exemplary implementation will produce the best, likewise with the mother's coping strategy in overcoming the inferiority of her child. After making a plan and carrying it out, the results can change the child's attitude.

\section{DISCUSSION}

Inferiority that a person has because of feeling lack of others. Inferior attitude is very closely related to the minder. Inferiority is the opposite of superiority, which is permanently attached to a person in every phase of life. Inferiority is caused by being too dominant in self-deficiency so that it seeps into character. This can happen to children who lose a father figure either due to death or divorce from their mother. Inferiority not only occurs in adulthood but can occur in childhood (Booree, 1962/2010). As for the following characteristics of low self-behavior (Prayoga, 2013): a) always aloof and withdraw from the association; b) always hesitate in acting; c) do not want to compete positively. 
Inferiority arises because it feels less valuable when comparing themselves with friends who still have fathers. Inferiority arises due to the psychological inability to give judgment to the lessthan-perfect self. Feeling inferior can occur in a person in this phase of life. Therefore, inferiority is not a sign of abnormality (Yusuf, 2004). A person with advantages certainly has shortcomings, and shortcomings also have advantages (Marimbun, 2019). Inferiority occurs when a person is more likely to see the flaws. Therefore, one must be able to see its shortcomings and advantages objectively (Putri, 2018).

Single parents have a dual role in fulfilling their family life, such as meeting the psychological needs of children and meeting physical needs (Anggraheni, 2016). Single mothers cannot afford to divide their time between homework and work outside the home. Problems will occur when single mothers cannot divide their time between homework and work outside the home. When a single parent feels depressed about the problem of life, the burden of life will be heavier, impacting reduced affection for children. Therefore, single mothers need to make various efforts in dealing with various problems in their lives called coping (Prasetyawati, 2018). Almost everyone has problems just having different levels. There are demands to solve problems in stressful situations. Ways to overcome pressing demands are called coping. Coping is seen as a balancing factor in maintaining self-adjustment during stressful situations (Diah, 2010).

One form of a coping strategy used is problem-focused coping (Fatimah, 2018). Problemfocused coping strategies are actions directed toward problem-solving. A person will tend to use this behavior if they assess the problems they faces can still be controlled. Problem-centered coping behavior tends to be done if a person feels constructive can be done to the situation or believes that the resources at their disposal can change it (Hardiyanti \&Permana, 2019; Maryam, 2017).

Problem-focused coping is used to reduce stressors by learning new ways or skills. A person will tend to use this strategy if they believe they can change situations that bring stress. Adults use this method more often (Lestari, 2013; Smet, 1957/1994; Sujadi \& Wahab, 2017). Coping with stress directed at problems that bring stress (problem-focused coping) aims to reduce the demands that bring stress or enlarge resources to deal with it. The method used is a direct action method. Problem-focused coping, which consists of 3 types, namely: a) confrontation; the individual clings to stance and defends what they want, changes the situation aggressively and dares to take risks; b) seek social support; individuals trying to get help from others; c) plan for problem-solving; Individuals think about, create and devise problem-solving plans to be solved (Smet, 1957/1994). Mothers, such as 1) have also done the three types of problem-focused coping above) have confidence that the coping strategy provided will work; 2) have other assistance, such as asking for support from an uncle to become the father figure of the child left by father; and 3) have planning, implementation, and follow-up to coping strategies.

\section{CONCLUSION}

This study concluded related to the coping strategy of single mothers in overcoming the inferiority of children that the inferiority displayed by single mothers in Gampong Birem Puntong Kota Langsa arises due to the impact of losing the father figure that is always there and protects it. The absence of a father figure in the child's life eventually results in the child's attitude turning into inferior (inferior) towards the friends and only choosing to spend time in the house. 
Single problem-focused coping strategies overcome the inferiority of children in Gampong Birem Puntong Kota Langsa in the form of making plannings arranged according to the needs of the child, then carrying it out in accordance with the right time, overcoming obstacles when carrying it out, and having the last step in the form of follow-up to evaluate and supervise every development experienced by the child.

\section{REFERENCES}

Agustiani, M. (2019). Penerapan teknik cognitive restructuring untuk mengatasi low self-esteem remaja (Studi di Kelurahan Kamanisan Kecamatan Curug Kota Serang Provinsi Banten) [Undergraduate thesis, UIN Sultan Maulana Hasanuddin Banten]. http://repository.uinbanten.ac.id/4128/

Ahmadi, A. (2007). Psikologi sosial. Rineka Cipta.

Ahsyari, E. R. N. (2014). Kelelahan emosional dan strategi coping pada wanita single parent (Studi kasus single parent di Kabupaten Paser). Psikoborneo: Jurnal Ilmiah Psikologi, 2(3), 170176. http://e-journals.unmul.ac.id/index.php/psikoneo/article/view/3659

Akhzani, M. (2020). Upaya membentuk keluarga sakinah pada pernikahan dini di Desa Karanggede Kecamatan Arjosari Kabupaten Pacitan [Undergraduate thesis, IAIN Ponorogo]. http://etheses.iainponorogo.ac.id/12391/

Alwisol. (2009). Psikologi kepribadian. UMM Press.

Andayani, S. (2016). Kekerasan seksual terhadap istri dalam perspektif hifdz al-nasl (keturunan) [Undergraduate thesis. Universitas Islam Negeri Alauddin Makassar]. http://repositori.uinalauddin.ac.id/838/

Andriana, R. (2020). Penerimaan diri remaja yang memiliki ayah dan ibu tiri di Kelurahan Sawah Lebar Kota Bengkulu. [Undergraduate thesis, IAIN Bengkulu].

Anggraheni, D. A. (2016, February 19-20). Fenomena perceraian: makna kebahagiaan dalam sudut pandang single mother. [Paper presentation], 122-127. Seminar ASEAN 2nd Psychology \& Humanity, Malang, Indonesia.

Arikunto, S. (2014). Prosedur penelitian: Suatu pendekatan praktik,. Rineka Cipta.

Booree, G. (2010). Personality theory: Melacak kepribadian anda bersama psikolog dunia, (Inyiak Ridwan Muzir, Trans.) Prismasophie. (Original work published 1952)

Damayanti, D., \& Dewi, R. (2017). Stigma pada perempuan single parent dengan HIV positif (Studi kualitatif). Jurnal Kesehatan Metro Sai Wawai, 10(2), 55-66. 10.26630/jkm.v10i2.1727

Departemen Agama RI. (2009). Al-Qur'an dan terjemahnya. Tiga Serangkai.

Diah, M. F. (2010). Perbedaan problem focused coping dalam menghadapi masalah pada pria dan wanita yang menjalani pacaran jarak jauh di masa dewasa awal. [Undergraduate thesis, Univeristas Sanata Dharma Yogyakarta].

Fatimah, M. (2018). Strategi coping dan distorsi kognitif pada ibu tunggal di Yogyakarta. Insight: Jurnal Ilmiah Psikologi, 20(1), 29-41. https://doi.org/10.26486/psikologi.v20i1.631

Fitria, C. I., Yusmami, \& Marimbun. (2021). Manajemen stres istri yang melangsungkan 
pernikahan dini. JAMBURA Guidance and Counseling Journal, 2(1), 36-43. https://doi.org/10.37411/jgcj.v2i1.637

Gustiawati, S., \& Lestari, N. (2018). Aktualisasi konsep kafa'ah dalam membangun keharmonisan rumah tangga. Mizan: Journal of Islamic Law, 4(1), 33-86. https://doi.org/10.32507/mizan.v4i1.174

Hardiyanti, R., \& Permana, I. (2019). Strategi coping terhadap stress kerja pada perawat di rumah sakit: Literatur review. Jurnal Keperawatan Muhammadiyah, 4(2).\, 73-81. http://journal.umsurabaya.ac.id/index.php/JKM/article/view/2599

Hasibuan, M. R. (2016). Pengarub konflik keluarga terhadap akblak remaja di Desa Mompang Kecamatan Barumun Kabupaten Padanglawas [Undergraduate thesis, IAIN Padangsidimpuan]. http://etd.iain-padangsidimpuan.ac.id/2460/

Isma, N. (2016). Peranan orang tua tunggal (single parent) dalam pendidikan moral anak (Studi kasus delapan orang ayah di Desa Songing Kecamatan Sinjai Selatan Kabupaten Sinjai). Jurnal Sosialisasi: Jurnal Hasil Pemikiran, Penelitian dan Pengembangan Keilmuan Sosiologi Pendidikan, 3(1), 1-5. https://doi.org/10.26858/sosialisasi.v3i1.2345

Julia, H., Jarnawi, \& Indra, S. (2019). Pola pengasuhan pada konteks kematangan emosional ibu single parent. Indonesian Journal of Counseling and Development, 1(1), 31-49. https://doi.org/10.32939/ijcd.v1i1.370

Kamalin, M. (2020). Konstruksi keluarga ideal sebagai fondasi kebidupan bernegara menurut Taqiyuddin al-Nabhani [Doctoral dissertation, Universitas Islam Negeri Sultan Syarif Kasim Riau]. http://repository.uin-suska.ac.id/27971/

Layliyah, Z. (2013). Perjuangan hidup single parent. The Sociology of Islam, 3(1). http://jurnalfisip.uinsby.ac.id/index.php/JSI/article/view/39

Lestari, D. W. (2013). Penerimaan diri dan strategi coping pada remaja korban perceraian orang tua. Psikoborneo: Jurnal Ilmiah Psikologi, 1(4), 196-203. http://ejournals.unmul.ac.id/index.php/psikoneo/article/view/3515

Linuwih, T. S. (2020). Perilaku keagamaan bagi anake single parent: studi kasus di Griya Kebraon Surabaya [Undergraduate thesis, UIN Sunan Ampel Surabaya]. http://digilib.uinsby.ac.id/44398/

Marimbun, M. (2019). Minat membaca dan implementasinya dalam Bimbingan dan Konseling. ENLIGHTEN: Jurnal Bimbingan Konseling Islam, 2(2), 74-84. https://doi.org/10.32505/enlighten.v2i2.1361

Maryam, S. (2017). Strategi coping: Teori dan sumberdayanya. Jurnal Konseling Andi Matappa, 1(2), 101-107. http://dx.doi.org/10.31100/jurkam.v1i2.12

Matul Hikmah, Y. (2020). Peran tokoh agama dalam meningkatkan nilai nilai hukum keluarga islam untuk mencegah KDRT bagi pasangan suami isteri di Desa Lubuk. Harjo Kecamatan Bayung Lencir [Undergraduate thesis, UIN Raden Fatah Palembang]. http://repository.radenfatah.ac.id/7996/

Munawaroh, A., \& Christiana, E. (2021). Inferiority remaja pelaku bullying di sekolah menengah pertama. Jurnal BK Unesa, 12(2), 134-143. https://jurnalmahasiswa.unesa.ac.id/index.php/jurnal-bk-unesa/article/view/36484 
Muttaqien, M. I. (2013). Self disclosure pada remaja difabel [Undergraduate thesis, Universitas Muhammadiyah Surakarta]. http://eprints.ums.ac.id/25378/

Nabit, Y. P., Keraf, M. K. . A., \& Anakaka, D. L. (2019). Strategi coping stres pada ibu single parent pasca ditinggal suami merantau. Journal of Health and Behavioral Science, 1(4), 241-261. https://doi.org/10.35508/jhbs.v1i4.2108

Novitasari, D. A. (2020). Pola asuh single parent dalam mendidik, mendisiplinkan dan melindungi anak [Undergraduate thesis, Universitas Airlangga]. http://repository.unair.ac.id/98516/

Prasetyawati, I. (2018). Strategi coping pada ibu single parent. [Undergraduate thesis, Universitas Muhammadiyah Surakarta].

Prayoga, S. A. (2013). Pola pengasuban anak pada keluarga orangtua tunggal (Studipada 4 orangtua tunggal di Bandar Lampung). [Undergraduate thesis, Universitas Lampung].

Putri, K. D. (2018). Hubungan antara inferiority feelings dengan agresivitas pada remaja. [Undergraduate thesis, UIN Sunan Ampel Surabaya].

Septianita, G., Abdurrahmansyah, \& Fauzi, M. (2019). Peran pendidikan in-formal dalam mendidik anak pada keluarga broken home di Kelurahan Bukit Lama Kota Palembang. Jurnal PAI Raden Fatah, 1(1), 47-61. https://doi.org/10.19109/pairf.v1i1.3009

Silvyana, F. (2018). Striving for superiority pada remaja penyandang disabilitas fisik. [Undergraduate thesis, UIN Sunan Ampel Surabaya].

Smet, B. (1994). Psikologi kesehatan, (Anshori, Trans) Grasindo. (Original work published 1957)

Sugiyono. (2017). Metode penelitian kuantitatif, kualitatif dan R\&D. Alfabeta.

Sujadi, E., \& Wahab, M. (2017). Strategi coping korban bullying. Tarbawi: Jurnal Ilmu Pendidikan, 13(2), 21-32. http://ejournal.iainkerinci.ac.id/index.php/tarbawi/article/view/190

Yulilla, D. (2017). Prinsip individual Adler pada atlet tuna daksa di Kota Tenggarong Kabupaten Kutai Kartanegara. Jurnal PSIKOBORNEO, 5(4), 590-597. http://ejournals.unmul.ac.id/index.php/psikoneo/article/view/4479

Yusuf, S. (2004). Mental hygiene. Pustaka Bani Quraisy. 